\title{
Conflict Related Incidents on Board Ships: An Online News Content Analysis
}

\section{Egemen Ertürk, Bayram Bilge Sağlam}

Conflicts, while being unavoidable in an unorthodox workplace such as the ship, might produce serious consequences. Therefore, this study aims to identifying and classifying the reasons and the consequences of conflict related incidents on board that have made the international news. For this aim twenty-two news articles on conflict related incidents have been gathered from eight maritime industry specific online news outlets and a content analysis has been carried out to illustrate the role of conflict in these news-worthy incidents. The results show that conflict can be observed in three categories: (1) Conflict between the crew members and the shipowner/ship management companies; (2) conflict between superiors and subordinates; and (3) conflict among crew members. In the first category, "unpaid wages" and "inadequate working conditions", in the second category, "abuse of power and authority" and "intolerance to criticism", and in the last category "fight among crew members" due to various reasons, such as ethnical differences and exclusion are found to be prevailing reasons for conflict situations that may result in dire

\section{KEY WORDS}

$\sim$ Conflict Management

$\sim$ Seafarers

$\sim$ Online news

$\sim$ Content Analysis

\author{
Dokuz Eylul University, Maritime Faculty, Maritime Business and Administration \\ Department, Turkey \\ e-mail: egemen.erturk@deu.edu.tr
}

doi: 10.7225/toms.v10.n01.018

This work is licensed under (cc) BY

Received on: Feb 24, 2021 / Revised on: Apr 9, 2021 / Accepted on: Apr 17, 2021 / Published: Apr 20, 2021 consequences. Even though these incidents are irreversible, the content analysis carried out in this study highlights several policy implications that can be implemented to alleviate the intensity of conflict situation on board.

\section{INTRODUCTION}

The ship, which is the seafarer's workplace, is undeniably different than a conventional office setting and the shift of a seafarer is disparate to those of white-collar employees. When International Maritime Organization (IMO) named the year 2010 as "The Year of the Seafarer", their Secretary-General defined the seafaring job as a difficult and demanding profession where, after a long and stressful shift, there is no return to one's home, to one's family or friends; no place to go to blow off steam, and no change of scenery, just the ongoing operation of the ship (Mitropoulos, 2010). As can be understood from this definition, ship is not only the workplace of a seafarer, but the living space as well, and this situation continues for months on end.

The issue of conflict, its reasons, consequences, and management in workplaces have long been topics that scholars of various disciplines have focused on. As conflict in the workplace has visible consequences on people, their behaviour and, as a result, the performance of their organisations (Suliman and Abdulla, 2005), this should not come as a surprise. There are various ways that workplace conflict can be manifested, ranging from minor disagreements to severe physical altercations and might be caused by reasons including, but not limited to insults, injustice, discrimination of any kind, unfairness, obstruction of goals, incompetence, bullying, and verbal or physical aggression (Scheiman and Reid, 2008). Considering the fact that almost every adult spends a significant portion of their time at their place of work (Lipsky et al., 2016), understanding the nature of workplace conflict is the first step towards developing a countermeasure. 
When it comes to conflict in seafaring profession, studies focusing on the matter are hard to come by. The antecedents of conflict such as mental health (Iversen, 2012), psychological stress (Carotenuto et al. 2012), being apart from one's family (Thomas et al., 2003) and fatigue (Jepsen et al., 2015) have all been the focus of various studies found in maritime literature; however, they are yet to be linked with or researched in the context of conflict.

Even though the dire consequences of conflict situations on board ships are known to the parties concerned, more and more incidents resulting from conflict seem to be making the news. While in the maritime industry issues such as accidents, detention, and arrest can be easily recorded and tracked, social phenomena such as conflict are hard to measure and monitor (Human Rights at Sea, 2020). For this reason, news that cover incidents caused by conflict represent an important source for understanding the effects of conflict situations that occur on board ships, as what the public deems important is often based on the narrative produced by the media outlets (Brooks and Hebert, 2006). In addition to that, media's power to focus people's attention on and off of certain issues often decides which of those issues will be tackled or ignored by the decision makers (Fursich, 2010).

Therefore, the aim of this study is to identify and classify the reasons and the consequences of conflict related incidents on board that have made the international news. In pursuit of this aim, news content analysis method has been implemented on twenty-two news articles published on eight maritime news websites. The classification of the investigated reasons for conflict is carried out taking into account the parties involved in conflict (among crew members and between crew members and the shipowner/ship management company).

\section{THEORETICAL FRAMEWORK}

There are various issues and hardships regarding seafaring, which can be defined as a high-risk occupation, and the safety and health aspects of work on board ships are a significant concern for every party involved (Jensen et al., 2006). The hardships of this occupation have all been duly researched in the literature; however, their connection with conflict have seldom been studied. When the conflict literature is reviewed, it can be seen that physical and psycho-social issues can be linked with conflict situations on different levels. On the other hand, literature on seafaring covers the phenomenon through the known conflict antecedents, such as working conditions, stress, fatigue, cultural factors, etc. implicitly.

Stressful conditions experienced by seafarers are related to both their occupational activities, such as noise, vibrations, heat, motion, disrupted sleep cycles (Lundh et al., 2010; Palella et al., 2016) and their personal traits, such as their capacity to deal with loneliness, lack of recreational time and activities, resilience, etc. Both these aspects are known to be the sources of physical and psychological stress (Carotenuto et al., 2013), and it can be argued that they can also act as antecedents to conflict.

When it comes to working conditions, Maritime Labour Convention (MLC), implemented by the International Labour Organization (ILO), is the sole legal reference point for minimum requirements. Following its implementation in 2006, studies show that MLC related detentions increased with the main reason for detention being on "accommodation, recreational facilities, food and catering" and "conditions of employment" (Grbic et al. 2015). In addition, overall deficiencies, as well as deficiencies related to work and living conditions, have declined, thereby indicating an overall improvement in conditions and an increased focus on seafarers' conditions on board (Fotteler et al., 2020). On the other hand, there are also studies that criticise the impact of MLC on improvement of working conditions, in which the subjects of the study (Danish seafarers) stated the impact of the convention on working conditions were minimal, and in some cases, none to be reported (Fotteler et al., 2018). With its aim of improving work and living conditions of seafarers, MLC contributes towards a minimisation of factors that lead to conflict situations, not just between the shipowner and the seafarers on board, but also among the seafarers as well. However, working conditions represent an ever changing issue that is subject to technological developments, resulting in consequences such as faster turnaround times, decreased and intensified personnel who face social isolation for extended periods of time (McVeigh et al. 2019), all of which requires up to date approaches for proper management.

However significant the physical working conditions might be, psycho-social stressors are just as important, if not more so. Empirical findings in the literature show that seafarers, being away from their families (Rengamani and Murugan, 2012; Thomas et al., 2003), living in isolation (Papachristou et al., 2015) and having underwhelming recreational possibilities (Oldenburg and Jensen, 2019), are among the most significant stressors on board. Considering that psychological well-being of an individual is undeniably linked with conflict situations at work (De Dreu et al., 2004) all of the above-mentioned sources of stress can also be considered a source for potential conflict situations. On top of these, the hierarchical organization structure on board ships provides another pressure point for seafarers, as they have to follow the advice and order of their superiors, even in cases where they disagree with them (Chung et al., 2017).

Another factor that can have an influence on conflict situations is the composition of crews on board. Approximately $65 \%$ of the world merchant fleet have resorted to the employment of multinational crews. Over ten per cent of the fleet is manned with crews that are composed of five or more nationalities (Kahveci et al., 2000). While the advantage of multinational crews is the reduced personnel costs for shipowners, it is also known to bring 
about problems regarding team management. According to the International Transport Workers' Federation, shipping industry suffers from the widespread discrimination against seafarers that come from low and middle income countries (ITF, 2006). This issue of discrimination is not limited to relationships between the crew members, but also presents itself in the employment agreement between the seafarer and shipowner, in the form of poorly paid contracts (McVeigh et al., 2019). Employment of seafarers from different nations means different cultures, religions, and languages being present on board simultaneously. For instance, multilingual crews can experience frustration due to poor use of working language, or the use of first language instead of common language breeds suspicion amongst the crew (Kahveci et al., 2000). Yuen et al. (2018) states that the stress and conflict is unavoidable in diverse crew settings and the way to improve this situation lies in training and educating the crew members on the issues of conflict management and cultural tolerance.

As can be seen, the existing seafaring literature provides an insight into what the antecedents of conflict might be. However, there is not a satisfactory number of studies that puts the issue of conflict in the focal point. This shortage of conflict related studies in the literature, coupled with an ever increasing number of disturbing news that is the consequence of conflict situations, show the necessity of further studies from the point of view of conflict management.

\section{METHODOLOGY}

In the last twenty years there has been a steady decline in the traditional news industry, caused by the disruptive innovation represented by the online news outlets. This transition has also been embraced by the industry-oriented news outlets, since it allows greater reach to potential industry members. In a methodological sense, this growth of online news outlets and articles, has slowly but firmly formed a dataset that can be used for tracking and analysing the industrial trends in all aspects. Conflict, being one of the ever-present and ever-growing social phenomenon in seafaring industry, can also be evaluated through the content analysis of related online news, considering that it is one of the duties of the media to define problems and frame issues as potential risks (Jönsson, 2011). "Cases of conflict that make the news" can be argued to be representative of a smaller portion of the phenomenon of conflict, since they only cover conflict situations that end in dire consequences. Nevertheless, it is important to analyse this news as it is exactly the kind of consequences that the policy makers are trying to avoid. Therefore, in order to better understand the phenomenon of conflict on board ships, this study has been designed with exploratory approach, built upon inductive content analysis.

In order to define the keywords that will be the basis of the online news content analysis, structured interviews have been carried out with twenty seafarers who are actively working on board. In the interviews, participants were briefed about the aim of this study and then were asked to provide consequences of conflict situations that can be used as keywords for the initialisation of the content analysis. Within this context, apart from "conflict" as an all-inclusive keyword, keywords of "mutiny", "suicide", "stabbing", "murder", "harassment", "bullying", and "assault" were decided on and later these keywords were searched on "seanews.co.uk", "marineinsight.com", "maritimeexecutive.com", "fleetmon.com", "g.captain.com", "setrademaritime.com", "safety4sea.com", and "denizhaber.com" between the dates of 15.10.2020 and 15.12.2020, without setting any limit on articles' publication date. When the news on the mentioned websites was found to be unsatisfactory regarding the context, further follow up was carried out by the authors by running a separate web search on the news article in question. At the end of the search process, twenty-nine news entries related with the keywords were found, thus forming the initial dataset of this study. Later, there were several extractions from the dataset due to the content of the news in question. News that came up when the keyword was searched but was not necessarily linked with conflict, conflict issues that is caused by external agents, such as stowaways and pirates, and incidents that occurred on vessels other than freight vessels (e.g. cruise vessels, fishing boats, military vessels) was excluded from this analysis. In the end, twenty-two news entries have formed the final dataset of the study.

Organisation and analysis of the data have been carried out using MaxQDA 2018 qualitative data analysis software. The use of such software in qualitative research has become wide-spread among scholars since it allows for reducing manual and clerical tasks and saves time, while also helping with the handling of large amount of qualitative data with improved flexibility and validity (John and Johnson, 2000). The dataset has been coded by the authors separately and the coding procedure has been designed on ad hoc coding basis, with the aim of categorising the articles based on the sources of conflict, consequences of conflict, and the conflicting parties. Findings have been tabulated according to the above mentioned variables and the name of the ship and flag.

\section{RESULTS}

The content analysis of the online news articles provided a categorisation that consists of three categories of conflict. These categories are (1) conflict between the crew members and the shipowner/ship management companies; (2) conflict between superiors and subordinates; and (3) conflict among crew members. These categories include 8,6 , and 8 cases respectively. The details about the cases are presented in Table 1 and findings are further discussed in their related subheadings. 
Table 1.

Results of the content analysis.

\begin{tabular}{|c|c|c|c|c|c|c|}
\hline & Name of the Ship & Flag & $\begin{array}{l}\text { Source(s) of } \\
\text { Conflict }\end{array}$ & $\begin{array}{l}\text { Consequence(s) } \\
\text { of Conflict }\end{array}$ & News Outlet & Publication Date \\
\hline \multirow{8}{*}{ 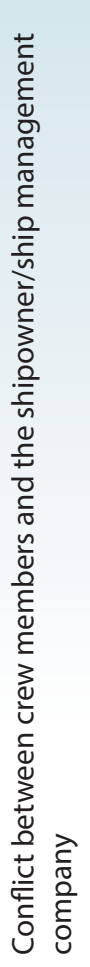 } & Harmony 1 & Singapore & Unpaid wages & Mutiny & fleetmon.com & 26.08 .2013 \\
\hline & M/V Vier Harmoni & Indonesia & Unknown & Mutiny & gcaptain.com & 17.08 .2016 \\
\hline & M/T Zoya 1 & Panama* & Unpaid wages & $\begin{array}{l}\text { Two of the crew } \\
\text { have tried to } \\
\text { commit suicide }\end{array}$ & $\begin{array}{l}\text { maritime- } \\
\text { executive.com }\end{array}$ & 18.04.2018 \\
\hline & M/V Halani 1 & $\begin{array}{l}\text { St Vincent and } \\
\text { Grenadines* }\end{array}$ & Unpaid wages & $\begin{array}{l}\text { Mental health } \\
\text { problems, threat } \\
\text { of suicide }\end{array}$ & $\begin{array}{l}\text { marineinsight. } \\
\text { com }\end{array}$ & 31.01 .2019 \\
\hline & Anna-Elisabeth & Liberia* & Inadequate stores & $\begin{array}{l}\text { Detention of the } \\
\text { ship }\end{array}$ & $\begin{array}{l}\text { seanews.co.uk, } \\
\text { marineinsight. } \\
\text { com, maritime- } \\
\text { executive.com }\end{array}$ & 27.03.2019 \\
\hline & Gannet S & Malta* & $\begin{array}{l}\text { Inadequate } \\
\text { working } \\
\text { conditions, } \\
\text { overworking }\end{array}$ & $\begin{array}{l}\text { An intern was } \\
\text { found dead due } \\
\text { to unsafe working } \\
\text { conditions }\end{array}$ & denizhaber.com & 16.08 .2019 \\
\hline & Tomini Destiny & Marshall Islands* & $\begin{array}{l}\text { Refusal of cargo } \\
\text { operations due } \\
\text { to Covid-19 } \\
\text { concerns }\end{array}$ & $\begin{array}{l}\text { Interruptred } \\
\text { commercial } \\
\text { operations }\end{array}$ & $\begin{array}{l}\text { maritime- } \\
\text { executive.com }\end{array}$ & 09.04 .2020 \\
\hline & Peristil & Croatia & $\begin{array}{l}\text { Overdue crew } \\
\text { change due to } \\
\text { Covid-19 }\end{array}$ & Mutiny & fleetmon.com & 28.06 .2020 \\
\hline \multirow{6}{*}{ 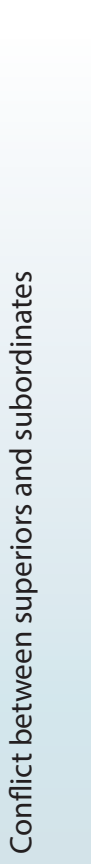 } & O.M. Agarum & Liberia* & Unknown & $\begin{array}{l}\text { Second officer } \\
\text { was stabbed, } \\
\text { master is missing }\end{array}$ & fleetmon.com & 06.10 .2013 \\
\hline & MSC Giannina & Portugal & $\begin{array}{l}\text { Operational } \\
\text { disputes }\end{array}$ & $\begin{array}{l}\text { Master is missing } \\
\text { (suspected of } \\
\text { murder) }\end{array}$ & $\begin{array}{l}\text { maritime- } \\
\text { executive.com }\end{array}$ & 08.11 .2017 \\
\hline & Tintomara & Liberia* & $\begin{array}{l}\text { Bullying, } \\
\text { non-payment } \\
\text { of overtime, } \\
\text { overworking, } \\
\text { inadequate stores }\end{array}$ & $\begin{array}{l}\text { Detention of the } \\
\text { ship, removal of } \\
\text { the master }\end{array}$ & $\begin{array}{l}\text { seanews.co.uk, } \\
\text { maritime- } \\
\text { executive.com }\end{array}$ & 26.02.2018 \\
\hline & STI Guard & Marshall Islands* & $\begin{array}{l}\text { Criticism of duty } \\
\text { performance }\end{array}$ & $\begin{array}{l}\text { Master was } \\
\text { stabbed }\end{array}$ & safety4sea.com & 06.02 .2019 \\
\hline & Sprit of Hamburg & Isle of Man* & $\begin{array}{l}\text { Under } \\
\text { investigation }\end{array}$ & $\begin{array}{l}\text { Murder of the } \\
\text { master }\end{array}$ & $\begin{array}{l}\text { fleetmon.com, } \\
\text { maritime- } \\
\text { executive.com, } \\
\text { gcaptain.com, }\end{array}$ & 17.04 .2020 \\
\hline & M/T New Horizon & Hong Kong & Harassment & $\begin{array}{l}\text { Deck cadet } \\
\text { missing under } \\
\text { suspicious } \\
\text { circumstances }\end{array}$ & $\begin{array}{l}\text { marineinsight. } \\
\text { com }\end{array}$ & 19.09 .2020 \\
\hline
\end{tabular}




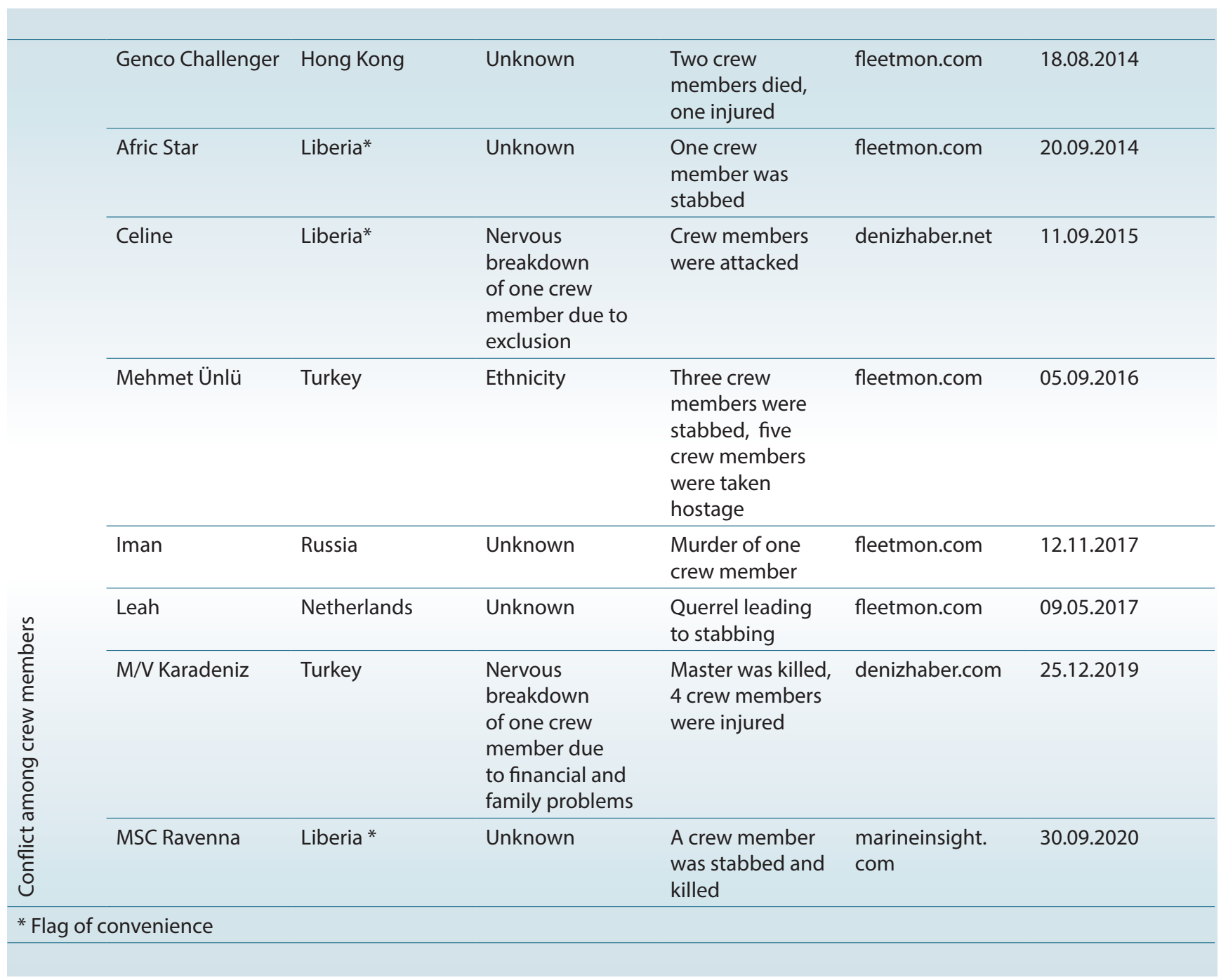

\subsection{Conflict between Crew Members and the Shipowner/Ship Management Company}

Results show that the conflict between the crew members and the shipowner/ship management companies can be observed on two prevailing subjects, which are "unpaid wages" and "inadequate working conditions". The cases of "M/V Harmony 1", "M/V Halani 1" and "M/T Zoya 1" are prime examples that show the extent of the conflict related consequences unpaid wages can lead to. In the case of M/V Harmony 1 , the crew was lied to by the owner and left with four months of unpaid wages without the right of repatriation, which lead to a mutiny by the crew members. Similarly, crew members of M/T Zoya 1 were also not paid for four months and deprived of their right to be repatriated in which the condition led to two of the crew members to trying to commit suicide. Whereas in the case of M/V Halani 1, it can be seen that the issue of unpaid wages was all the direr, the period reaching almost two years, the ship and its crew being abandoned. The crew, who were living off by humanitarian aids at this point, suffered from increased fatigue, serious mental health problems, and suicidal tendencies.

The cases of the Anna-Elisabeth and the Gannet S show how inadequate working conditions can lead to conflict, and subsequently, serious consequences. The crew of the AnnaElisabeth were deprived of sufficient food and were also subject to bullying on board, which lead to complaints to authorities by the crew members and consequently, the detention of the vessel. It has been reported that due to the financial hardships the shipowning company was facing, they were not supplying the vessel with sufficient stores. In the case of the Gannet S, a deck cadet was forced to stay in a non-air conditioned room in which temperature reached 45 degrees Celsius and was forced to work an average of twenty hours a day. The cadet in question was reportedly forced to clean a tank twenty metres deep with a 
temperature of 50 degrees Celsius, which was by no means legal for a cadet to do. In the following days, the cadet was found dead in his quarters, the autopsy stating it was due to lung infection.

In the wake of Covid-19, the ongoing commercial concerns of shipowners present new challenges that might cause conflict situations between them and crew members. The case of the Peristil presents the hardships that can be endured during repatriation and crew change processes due to mandatory quarantine periods enforced by various countries. The fact that the seafarers who will leave the ship would be quarantined in containers for fourteen days in South Korea forced them to stay on board, which has led to conflict and fights among crew members who were confined on board for too long. The case of the Tomini Destiny shows another issue that might arise in this era of a pandemic, apart from repatriation and crew change issues. The master of the Tomini Destiny refused to discharge cargo where the operation would see 60 local stevedores boarding the ship, on the basis of his concern regarding the health of the crew members. The master raised his concerns on closely interacting with up to 60 stevedores to the shipowner, who wanted the operation to continue.

It can be deduced from these cases that in the foundation of crew member-shipowner conflicts lies the financial concerns of the shipowners. More precisely, in the downfall of the financial struggles, the first cost saving action being taken at the expense of the seafarers creates a tension between the parties. Moreover, the longer it takes for these conflict situations to be resolved, the harder it becomes for the seafarers to deal with these issues, since they already work and live in a harsh environment. In consideration, it is not hard to imagine some of these, escalating into extreme situations that make the news.

\subsection{Conflict between Superiors and Subordinates}

As this is the case in most of the workplaces, the relationships between superiors and subordinates are prone to conflict. In the case of ships, due to the hierarchical structure, there is more room for "abuse of power and authority" (Ertürk, 2020). On the other hand, conflict situation could also be presented in cases where the recipient of criticism coming from a superior, has a hard time accepting it, which can be labelled as "intolerance to criticism". The results of this study present examples on both of these ranges of superior-subordinate conflict.

The cases of the Tintomara and M/T the New Horizon are the two examples of conflict situations where the superiors were reportedly abusing their authority. The complaints of the crew members of the Tintomara regarding the master included issues such as culture of bullying, non-payment of overtime, long working hours, and shortage of supplies provided to them, which led to weight loss throughout the crew members. This complaint resulted in detention of the ship and removal of her master by local authorities. In the case of $\mathrm{M} / \mathrm{T}$ the New Horizon, a cadet who was complaining to his family about being harassed by his superior (a senior officer), and planning to take legal action, was declared missing under suspicious circumstances. The master of the vessel backed the claims of the cadet and stated the he had indeed been harassed by his senior officer.

The cases of STI Guard and MSC Giannina show instances where troubles in accepting criticism could potentially act as an antecedent for conflict situations with serious consequences. The master of STI Guard was stabbed by one of his officers. This officer, who was rumoured to be a second officer, was reportedly upset about master's criticism over his work performance. In the case of MSC Giannina, two crew members were arrested over their role in the master's suspicious disappearance and presumed death. Reportedly, these two seafarers were subject to disciplinary action filed by the master, over engine failures on two separate occasions throughout the same voyage, which caused the ship to be delayed. There are two more cases that resulted in one seafarer missing under suspicious circumstances (O.M. Agarum) and one being stabbed (the Spirit of Hamburg). However, the reasons for these conflict between superiors and subordinates are yet to be unearthed.

\subsection{Conflict among Crew Members}

Due to the ship being a difficult place of work, which presents various psycho-social stressors for its inhabitants, "fights among crew members" are not uncommon. More often than not, these crew fights tend to escalate into physical altercations. The cases that fall under the heading of conflict among crew members show that these altercations can result in physical harm, and even fatalities, when they are poorly managed. Two murdered and one injured in the Genco Challenger incident, one injured in the Afric Star incident, one murdered in M/V Iman incident, one injured in M/V Leah incident, three injured and five taken hostage in the Mehmet Unlu incident, one murdered in MSC Ravenna incident, one murdered and four injured in M/V Karadeniz incident, are all examples of the extent of what conflict related incidents might reach. When it comes to the reasons of these conflict situations, the investigated news failed to provide an answer, or merely provided a hearsay evidence. In the case of the Celine, where a seafarer attempted to set fire to the ship, injuring crew mates in the process, the news reported that the origins of the incident was rumored to be the exclusion of the seafarer by other members of the crew. In the case of the Mehmet Unlu, where the crew composition was multi-national, news reported the incident was rumoured to be caused by ethnic conflicts which led to a fight among the crew. 


\section{DISCUSSION}

This paper has investigated the conflict related incidents that have made the online news due to their serious consequences. However, it should be kept in mind that not every incident occurring on board ships has been reported, or could have consequently made the news. Hence the online news content that is the basis of this study is just the tip of the iceberg, which goes to show how serious of a deal conflict is in the seafaring industry. Even though scholars of different disciplines have researched issues that have made the ship a difficult place of work (e.g. fatigue, burn-out, job stress) the issue of conflict, which can be seen as a result of these difficulties, has not been sufficiently studied yet. The extent to which the conflict situations in seafaring can be understood by analysing the extreme incidents that have made the online news has yet to be fully understood. We therefore hope that the results of this study might shed some light on the direction that needs to be taken to better manage these situations. Otherwise, this type of news might damage the image of the seafaring profession, as well as the reputation of the shipowning companies where these incidents occur.

The content analysis that has been carried out in this framework has provided a categorisation of conflict related incidents in three groups, depending on the parties involved. These groups can be listed as conflict between crew members and the shipowner/ship management companies, conflict between superiors and subordinates, and conflict among crew members. For each of these three groups, the nature of conflict is different, whereby the approach to manage or eliminate these conflict reasons differ as well. For the conflict between crew members and the shipowner/ship management companies, the prevailing reasons have been found to be "unpaid wages" and "inadequate working conditions". These two reasons are undoubtedly related to financial factors of the shipowner, and any improvement to be made in these matters would subsequently decrease the possibility of conflict situations among the parties. As for the conflict between superiors and subordinates, it is a two-way street, where superiors might resort to "abuse of power and authority", and subordinates might experience "intolerance to criticism". Both of these underlying factors become manifest in times where hierarchical structure fails to operate as intended. Lastly, the conflict among crew members almost always presents itself with "fights among crew members". Even though the important aspect that is to be analysed here is the reason for these fights, the online content that is available lacks information on this matter. Still, the results include articles where "ethnicity" and "exclusion" were found to be reasons for conflict in real life examples.
However, this study has certain limitations based on the data that is accessible. Most of the information gathered from the online news articles from various sources are subject to verification and some information regarding the sources of conflict is speculated by the authors of the articles or reported by a limited number of witnesses. Still, this does not change the fact that consequences are very real and ever present. Therefore, the information on the cases should be taken with a grain of salt, keeping in mind the fact that some of the cases are still under investigation and, consequently, reported with very little detail. In addition, most of the initial coverage of the incidents has been left without a follow-up article, thereby contributing toward the reasons for conflict remaining unknown. Further studies can enhance our findings by carrying out studies with primary data (e.g. focus group studies with seafarers who have actually experienced such incidents on board). Another important point that has been brought to light by the findings is the role of Covid-19 in presenting new types of hardships for shipowners and seafarers alike. In this context, further investigation of the role of Covid-19 in conflict situations would be helpful for understanding the extent of its effect on seafaring industry.

\section{CONCLUSION}

The findings of the study provide policy and managerial implications for the decision makers in the maritime industry and managers of shipowning/ship management companies. As the subjects of the conflict situations on board, seafarers must have a grasp on conflict management skills. Standards of Training Certification and Watchkeeping (STCW) requires officers to have certain managerial and operational competencies and ratings to have only operational competencies. While it might be problematic to expect only operational competencies from the ratings, it is also lacklustre that managerial competencies required for the officers do not include any competency related with conflict management. Other than personal competencies, working conditions on board are also found to be an important reason for conflict. MLC was introduced with the aim of improving the working conditions of seafarers on board. However, our result show that several conflict related incidents have occurred due to non-compliance with MLC mandated regulations. It can also be noted that more than half of the news covered in this study had vessels flying convenience flags. Therefore, the port state and flag state inspections should focus more strictly on the enforcement of MLC regulations, which would help improve the overall industry standards. The managers of shipowning/ship management companies can also play a distinct role in conflict management. Especially in the recruitment process, psychological and psychosocial tests can be carried out to determine the conflict tendency 
of the candidate. Tests that identify the conflict management style would also be beneficial for creating an inventory of the characteristics of said candidate. Other than the recruitment process, seafarers should be trained and educated on issues that are related to conflict, such as diversity and inclusion, and communication skills.

\section{REFERENCES}

Brooks, D. \& Hébert, L., Gender, Race, and Media Representation. The SAGE Handbook of Gender and Communication, pp.297-318. Available at: http://dx.doi.org/10.4135/9781412976053.n16.

Carotenuto, A. et al., 2012. Psychological stress in seafarers: a review. International Maritime Health, 63(4), pp. 188-194.

Chung, Y.-S., Lee, P.T.-W. \& Lee, J.-K., 2017. Burnout in seafarers: its antecedents and effects on incidents at sea. Maritime Policy \& Management, 44(7), pp.916-931. Available at:

http://dx.doi.org/10.1080/03088839.2017.1366672.

De Dreu, C.K.W., van Dierendonck, D. \& Dijkstra, M.T.M., 2004. Conflict at work and individual well-being. International Journal of Conflict Management, 15(1), pp.6-26. Available at:

http://dx.doi.org/10.1108/eb022905.

Ertürk, E., (2020). A qualitative study on conflict reasons in Turkish seafarers' workplace. Dokuz Eylül Üniversitesi Denizcilik Fakültesi Dergisi, pp.3-4. Available at: http://dx.doi.org/10.18613/deudfd.837277.

Fotteler, M.L., Jensen, O.C. \& Andrioti, D., 2018. Seafarers' views on the impact of the Maritime Labour Convention 2006 on their living and working conditions: results from a pilot study. International Maritime Health, 69(4), pp.257-263. Available at: http://dx.doi.org/10.5603/imh.2018.0041.

Fotteler, M.L., Andrioti Bygvraa, D. \& Jensen, O.C., 2020. The impact of the Maritime Labor Convention on seafarers' working and living conditions: an analysis of port state control statistics. BMC Public Health, 20(1). Available at: http://dx.doi.org/10.1186/s12889-020-09682-6.

Fürsich, E., 2010. Media and the representation of Others. International Social Science Journal, 61(199), pp.113-130. Available at: http://dx.doi.org/10.1111/j.1468-2451.2010.01751.x.

Grbić, L., Ivanišević, D. and Čulin, J., 2015. Detainable Maritime Labour Convention 2006-related deficiencis found by Paris mou authorities. Pomorstvo, 29(1), pp. 52-57.

The International Transport Workers' Federation, 2016. ICS-ITF Guidance on eliminating shipboard harassment and bullying.

Human Rights at Sea, 2020. Flag States \& Human Rights Report 2020, Protecting Human rights at sea: An evaluation of flag state practice in monitoring, reporting and enforcing human rights obligations on board vessels. University of Bristol Human Rights Implementation Centre

Iversen, R. T., 2012. The mental health of seafarers. International Maritime Health, 63(2), pp. 78-89.
Jensen, O.C. et al., 2006. Working conditions in international seafaring. Occupational Medicine, 56(6), pp.393-397. Available at: http://dx.doi.org/10.1093/occmed/kql038.

Jepsen, J.R., Zhao, Z. \& Van Leeuwen, W.M.A., 2015. Seafarer fatigue: a review of risk factors, consequences for seafarers' health and safety and options for mitigation. International Maritime Health, 66(2), pp.106-117. Available at: http://dx.doi.org/10.5603/imh.2015.0024.

John, W.S. \& Johnson, P., 2000. The Pros and Cons of Data Analysis Software for Qualitative Research. Journal of Nursing Scholarship, 32(4), pp.393-397. Available at: http://dx.doi.org/10.1111/j.1547-5069.2000.00393.x.

Jönsson, A.M., 2011. Framing Environmental Risks in the Baltic Sea: A News Media Analysis. AMBIO, 40(2), pp.121-132. Available at: http://dx.doi.org/10.1007/s13280-010-0124-2.

Kahveci, E., Lane, T. and Sampson, H., 2000. Transnational Seafaring Communities. Cardiff University, Wales.

Lundh, M. et al., 2011. Working conditions in the engine department - A qualitative study among engine room personnel on board Swedish merchant ships. Applied Ergonomics, 42(2), pp.384-390. Available at: http://dx.doi.org/10.1016/j.apergo.2010.08.009.

McVeigh, J. et al., 2019. Identifying Predictors of Stress and Job Satisfaction in a Sample of Merchant Seafarers Using Structural Equation Modeling. Frontiers in Psychology, 10. Available at:

http://dx.doi.org/10.3389/fpsyg.2019.00070.

Mitropoulos, E. E., 2010. World Maritime Day 2010 Year of the Seafarer. IMO News, 3, p. 5.

Oldenburg, M. \& Jensen, H.-J., 2019. Stress and Strain among Seafarers Related to the Occupational Groups. International Journal of Environmental Research and Public Health, 16(7), p.1153. Available at: http://dx.doi.org/10.3390/ijerph16071153.

Palella, B.I., Quaranta, F. \& Riccio, G., 2016. On the management and prevention of heat stress for crews onboard ships. Ocean Engineering, 112, pp.277-286. Available at: http://dx.doi.org/10.1016/j.oceaneng.2015.12.030.

Papachristou, A., Stantchev, D. \& Theotokas, I., 2015. The role of communication to the retention of seafarers in the profession. WMU Journal of Maritime Affairs, 14(1), pp.159-176. Available at: http://dx.doi.org/10.1007/s13437-015-0085-1.

Rengamani, J. and Murugan, M. S., 2012. A study on the factors influencing the seafarers' stress. AMET International Journal of Management, 4(1), pp. 44-51.

Thomas, M., Sampson, H. \& Zhao, M., 2003. Finding a balance: companies, seafarers and family life. Maritime Policy \& Management, 30(1), pp.59-76. Available at: http://dx.doi.org/10.1080/0308883032000051630.

Yuen, K.F. et al., 2018. Determinants of job satisfaction and performance of seafarers. Transportation Research Part A: Policy and Practice, 110, pp.1-12. Available at: http://dx.doi.org/10.1016/j.tra.2018.02.006. 